Download

UDC 338.48-53:63(477.83)

https://doi.org/10.17721/2308-135X.2020.5

8.36-42

Tsymbala Olga Stefanivna,

candidate of historical sciences Lviv Institute of Economy and Tourism, Lviv, Ukraine, e-mail: olga.lviv1256@gmail.com

Dorosh Julia Stepanivna Lviv Institute of Economy and Tourism, Lviv, Ukraine, e-mail: yudorosh07@gmail.com

\title{
DEVELOPMENT OF TOURIST ORIENTED FARMS OF LVIV REGION
}

Purpose. Characterize the development trends of the network of tourist-oriented farms which operate within the Lviv region. Systematize information about their specialization and key areas of work, identify and describe the main groups of farms in Lviv region in view of the priority of their activities, as well as reveal the features of the tourist offers for visitors and tourist groups.

Methods. The research used the method of analysis to study the literature and information sources on the research topic; the method of scientific systematization is applied to the selection of tourist oriented farms of Lviv region and the characteristic of key areas of their activities; the cartographic method allowed to visualize the location of the studied farms within 
the region by forming a map of Lviv region with the indication of settlements where the tourist-oriented farms operate.

Results. The role, place and significance of tourist-oriented farms for the development of rural tourism are outlined. The farms of Lviv region that are involved in the tourism sector, focused on the reception of tourists and presented in the information space are highlighted. The dominant group of tourist-oriented farms in Lviv region is formed by those farms that are engaged in the cultivation of cows, goats, sheep, specializing in the manufacture and sale of dairy products, especially various types of cheese. At the same time, a number of cheese factories have been formed within the region, operating on the basis of purchased raw materials. A separate group includes honey eco-farms, berry farms, snail farms, ostriches, etc. Systematized data on the specifics, features of the development of the studied farms are presented in the table, the main products and tourist services they offer on the market of tourist services are highlighted. A map of Lviv region with a presentation of the geography of location of tourist-oriented farms within the region are developed.

The scientific novelty of the obtained results lies in the generalization of information about the existing tourist-oriented farms of Lviv region and the analysis of their offer on the tourist market.

The practical significance lies in the systematization of relevant information about the current state of development of tourist oriented farms in Lviv region. The obtained scientific results can be used in the process of forming tours in Lviv region as well as in the educational process in the training of future specialists in the specialty «Tourism».

Keywords. Lviv region, rural tourism, tourist-oriented farm, excursion, tasting.

References:

1. Bananova ferma [Electronic resource]. - Mode of access: https://banana-plant.business.site/. 
2. Vidpochynkovyi kompleks - demonstratsiina pasika. Medovyi bliuz [Electronic resource]. Mode of access: https://medbluz.com.ua/.

3. Hastromandry Lvivshchynoiu / Upravlinnia turyzmu ta kurortiv Lvivskoi oblasnoi derzhavnoi administratsii. - Lviv, 2018. - 48 s.

4. Horbohory. Ahroturystychnyi klaster [Electronic resource]. - Mode of access: https://www.horbohory.com.ua/.

5. Horishevskyi P., Vasyliev V., Zinko Yu. Silskyi zelenyi turyzm: orhanizatsiia nadannia posluh hostynnosti. - Ivano-Frankivsk: Misto NV, 2003. - 148 s.

6. Dvi Kateryny [Electronic resource]. - Mode of access: https://theukrainians.org/dvi-kateryny/.

7. Zakhidnyi ravlyk [Electronic resource]. - Mode of access: http://www.zakhidnyy-ravlyk.com/.

8. Karpatskyi vodohrai [Electronic resource]. - Mode of access:

https://www.karpatskij-vodograj.com.ua/.

9. Lvivska oblasna derzhavna administratsiia: $\vee$ oblasti vidbulas persha zustrich chleniv turystychnoho hastroklubu Lvivshchyny. - 24 liutoho $2020 \mathrm{r}$. [Electronic resource]. - Mode of access: https://loda.gov.ua/news?id=50026.

10. Molochna ferma Fromages dElise: CHEVRETTE [Electronic resource]. - Mode of access: http://chevrette.com.ua/. 
11. MUKKO - molochna ferma Prykarpattia [Electronic resource]. - Mode of access: https://mykko.com.ua/.

12. Natsionalna turystychna orhanizatsiia Ukrainy: 2020 - rik rozvytku turyzmu v rehionakh ta silskykh terytoriiakh [Electronic resource]. - Mode of access:

http://www.ntoukraine.org/year2020_ua.html.

13. Ukrainiski ravlyky «Tante Snails» [Electronic resource]. - Mode of access: https://tantesnails.com/.

14. Faina Berry [Electronic resource]. - Mode of access: https://faynaberry.com/.

15. Fermerske hospodarstvo «Merynos Zakhid». - Rezhym dostupu: https://merinos-zahid.com/.

16. Tsymbala O., Dorosh Yu. Analiz rynku mobilnykh dodatkiv u sferi turyzmu / VIII Rehionalna naukovo-praktychna konferentsiia «Istoryko-kulturni pam'iatky Prykarpattia ta Karpat - vazhlyvi ob'iekty v rozvytku turyzmu» ( Lviv, 25 bereznia 2020 r.). - Lviv: LIET. - S. 295-303.

17. Busby G., Rendle S. The transition from tourism on farms to farm tourism // Tourism Management. - 2000. № 21. - R. 635-642.

Надійшла до редколегії 07.10.2020 